\title{
Perindo: The Emergence of The Business Party in Indonesia
}

\author{
Ahmad Zaki Fadlur Rohman ${ }^{1 \mathrm{a}}$, Laode Machdani Afala ${ }^{1}$ \\ ${ }^{1}$ Department of Government, Brawijaya University, Malang, Indonesia \\ ${ }^{a}$ Corresponding author: azacky64@gmail.com
}

\begin{abstract}
This paper tries to explain the phenomenon of the latest political party model development in Indonesia. During this time, the study of the party model is often based on social cleavage and electoral orientation. But, ahead of the 2019 election, there emerges a new Perindo party whose the root of formation is different from the previous parties. Based on the research result, Perindo party is a new type of political party in Indonesia that can be categorized as a business party. By using framework developed by Krouwel there are at least four characters of Perindo party as the first business party in Indonesia. First, the Perindo Party was established from a business network in an economic society and did not originate from a fraction of a political party previously existing in Parliament. In addition, the formation of the party is annealed and funded by a group of elites, not rooted from the grassroots. Second, candidate recruitment patterns tend to be open, and the range of electoral appeal tends to be broad with low party-id bonds. Third, policy strategies tend to be flexible and more oriented to the public office rather than the interests of the representative. Fourth, internal organization management tends to be professional and modern, although it is controlled hierarchically and centrally by party leaders.
\end{abstract}

\section{Keywords—perindo, business party, electoral, party model}

\section{INTRODUCTION}

This study attempts to capture the latest model of political party development in Indonesia that has never been explained in previous studies. The emergence of Perindo as a new political party is a new model in party typology studies. This is because Perindo was established from the MNC corporation network, has no clear social basis, and was not originate from the old party fractionalization like other new parties such as Gerindra, Demokrat, Hanura, and Nasdem. For this reason, the phenomenon of the Perindo party requires a special study.

In the period of the 1950s, the typology of political parties in Indonesia often refers to social cleavage. This is the way that Feith and Castle made the typology of political parties in 1955 into 5 (five) models: Radical Nationalism (PNI), Javanese Traditionalism (NU, PNI and PKI), Islam (NU and Masyumi), Democratic Socialism (Masyumi and PNI party wedges), and Communism (PKI) [1]. Of course, this type of typology cannot be used to understand Perindo that does not have a clear social basis.

After the first election of reformation in 1999, many studies on the typology of the party began to develop in Indonesia. As conducted by Dhakidae, the political party can be divided into two main paths, namely class and stream (aliran) paths [2]. The class path distinguishes the capitalist party that supports developmentalism like Golkar, with the party owned by the radical socialist workers like PRD. Meanwhile, the stream path distinguishes the party based on the view of the world and its problem, namely Islamic parties such as PPP, PBB, PK, with secular parties such as PDIP. While PAN and PKB are the middle paths as a meeting point between class and stream paths. This typology is also less able to explain the position of Perindo that carries welfare issues for the poor through the empowerment of entrepreneurship and its ideological position that has no historical root such as secular and Islamic parties.

The study of party typology was also developed by Ambardi by using social cleavage approach based on religious, regional, and class [3]. Furthermore, party-based cleavage between Java and non-Java was prominent before the 1955 election which also influenced the formation of the RIS (Republic of the United States of Indonesia). While the religious cleavage between Islam and secular has grown since the beginning of independence until post-reform between the Islamic party and the nationalist party. Meanwhile, class-based social classification began to strengthen in the 1970s, due to the new-order policy oriented to economic growth. This typology is also difficult to understand Perindo in which regional issues are not visible, as well as issues of class and diversity.

The latest party typology which is slightly able to explain Perindo is the emergence of match-all parties in Aminuddin's study, revealing that the tendency of new parties of 2009 elections such as Hanura and Perindo leads to the match-all party model [4]. This is because the two new parties are deemed not to have a clear social basis so that they take advantage of all existing social basis for the sake of electoral. Meanwhile, in the catch-all party model, even it no longer uses its social basis to expand the electoral reach, but never had a clear social basis. The model is only able to explain Perindo from the electoral aspect, but has not been able to explain how it is formed from new business networks and not formed through the old business networks and old elites as Hanura formed by Wiranto, and Gerindra formed by Prabowo. Therefore, through the concept of party typology developed by Krouwel [5] using the four dimensions of the party model, namely genesis, ideology, electoral, and organization, this study tries to explain how Perindo is specifically different from 
previous party models in Indonesia, where there is a tendency to lead to a business party model.

\section{RESEARCH METHOD}

To understand how Perindo develops as a business party in Indonesia, this study uses case study research methods. The use of case study for researchers is considered important because, at least, there are two considerations. First, the focus of research in case studies is an in-depth analysis of a single or double case that is considered unique [6]. This is in accordance with the emergence of Perindo party as a new case in the development of political parties in Indonesia. Second, the unit of analysis in the case study does not focus on the individual, but rather emphasizes the explanation of events, programs, and activities involving many individuals. It is important to analyze Perindo's activities as an organization which includes events, programs, and activities involving many actors.

\section{RESULT AND DISCUSSION}

\section{A. Model of Business Firm Party}

The Business Party is the last model of the development of political parties in Europe, and is not found in America. Hopkin and Paolucci (1999) describe the Forza Party owned by an Italian, Berlusconi, as the first example of the emergence of a business party. According to Andre Krouwel, there have four criteria that can be used as an instrument in analyzing the company's business party as following [5].

1. The dimension of genesis or origin, the indicators are: a). the party is formed by an external elite of the state or not of the elite in parliament, b). the origin of the party is formed on the initiative and personal resources.

2. Ideological dimension, the indicators are: a). in the policy process, a party tends to be flexible and not bound by a particular ideology b.) Party orientation tends to seek office (office seeking) rather than policy orientation.

3. Electoral dimension, the indicators are: a). elite recruitment patterns tend to be open and inclusive, $b$ ). in establishing relations with the electorate, the electoral appeal tends to be broad, but the party id is weak.

4. Organizational dimension, the indicators are: a). patterns of internal relations of party are hierarchical and centralized by party leaders, b). organizational structure is managed professionally based on capital intensity like in a company.

B. Perindo Party as a Model of Business Firm Party in Indonesia

\section{- Genesis Dimensions}

\section{External Origins/proximity to civil society}

The true origins of political parties are two distinctions, namely political party emerging through the internal process of parliament and the parliamentary external process. The Perindo Party is a new party in Indonesia that emerges from the external of parliament. Party Perindo was established by Hary Tanoesoedibjo or often well-known as HT which is a leading business actor in Indonesia. HT is a new figure who plunge in the field of politics. The same thing about the formation of Perindo party from the external parliament affirmed by Sahrianta Tarigan, that the formation of Perindo party structure is established by new people who join the political world and have proximity to HT [7].

Perindo party was formed from a community organization called Perindo in 2013. The organization is engaged in social and disaster issues. In the process of establishment, HT had stated that this organization is a first step to establish a political party. Perindo as mass organizations is often engaged in the social field and come down in every disaster with providing free ambulance, social service, cheap bazaar and fogging [8]. To support his ambition to President or Vice President of Indonesia, Perindo then was formed as political party.

\section{Initiatives and Personal Resources}

As a new political party, Perindo party has considerable political ambition to win the general election in 2019. This can be seen from some of the programs and campaigns by Perindo party. For the sake of the ambition, HT does not want halfhearted in acting to raise the Perindo party. In short, Perindo party resources are described as following:

1. Having a main figure. In building Perindo party, all cadres of Perindo party always build HT figure as the main figure to society. This can be seen in every political campaign of Perindo party both in the print and electronic mass media owned by HT.

2. Having a network of print and electronic mass media. HT has a number of major media namely RCTI, MNCTV, Global Tv, Inews Tv, Sindo newspaper, and okezone.com

3. Having a financial resources. In AD/ART, Perindo party itself does not regulate the financial resources of Perindo party, but for all activities Perindo party either to run the program or to build the infrastructure both in the center and in region entirely use personal bags of HT [9].

\section{- $\quad$ Electoral Dimension of Perindo Party}

\section{Open and Inclusive Elite Recruitment Patterns}

Perindo party has a fairly open and inclusive recruitment pattern. In an interview with Amyn Gultom, elite recruitment process conducted by Perindo party as a new party in Indonesia is by using mandate process to every level of region. After being mandated, cadres who have become members of board will be included in cadre training into their respective levels [10]. The Perindo Party implements the online registration legislation policy. Such registration is an effort by the Perindo party to screen elites from outside the Perindo party to be able to sit in the legislative and executive. Besides, in member recruitment process, the Perindo party has an open strategy facilitated by the online and offline registration [11]. It is conducted by Perindo party as an effort to get mass to support party vote. 


\section{Extensive Electoral Appeal with weak party relationships}

In talking about party appeal and relation, it will be related to the mass basis and party relationship with an organization identified with a group represented by the party. A political party must have a party identity stating that a political party represents a group in the community. As consequence, the political party will get support given by mass. It is because a supported political party will voice the mass interests as a reward. As some political parties in Indonesia, they have a stable vote gain because they have an identity that represents a community such as PKB with NU, PKS with Muslim students, and PAN with Muhammadiyah as their mass basis. A strongly linked political party with mass basis will have a stable vote in every election.

In an interview with Rahmat, the Perindo voters appeal is all classes of society, regardless of religion, ethnicity, and race. But, Perindo party focuses more on young people and productive ages in order to maximize Perindo's voice. Potentially, this party has a very wide electoral appeal. Perindo party is not left or right ideology, no religious or secular ideology. Therefore, basically the Perindo party does not have a concrete mass basis and does not have strong links to community groups with identities, but has extensive electoral appeal.

\section{- Ideological Dimension of Perindo Party}

\section{Flexible Strategic Policy}

Generally, the condition of political parties in Indonesia at this time tends to not have strong ideology to the public so that the ideology of the party tends to be non-binding. This condition leads to the emergence of personality and popularity as party identity. It affects to the difficulty to distinguish between one party and the other. Although, Perindo has never been part of the government, its ideological pattern is not much different from other new parties based on Pancasila. It is a flexible pattern, because Pancasila's ownposition is neither secular nor religious. The installing of Perindo's idiology is run by giving the training on the cadre from the top to the lower levels. This is conducted by Perindo for its cadres to animate Pancasila and to foster a sense of high nationalism. In practice, issues raised by Perindo tend to raise issues of welfare.

\section{Orientation of Office Seeking}

The tendency of the business parties have same characteristic in common with the cartel party that is oriented to gain the office (office seeking). As a new party in Indonesia, the strategic policy steps of Perindo party have not been too visible because the party still has not followed the election stage. Nevertheless, the tendency of Perindo oriented to office can be seen from the pattern of political behavior that tends to play safe. For example, it can be seen in the election of the Governor of DKI Jakarta. When looking at the chances of the Anies-Sandie couple to win in election, HT began to support the couple. Whereas, there is another couple of Ahok-Djarot who is ethnically closer with him in ethnic Chinese and nonMuslims. In addition, his business corporations in the media tend to support the government. This is at least a positive effect for his company in the media that is not regarded as the government's opposition.

\section{- Organizational Dimensions}

\section{Hierarchical and Centralistic Controls}

Basically, the party business model has a fairly weak party organizing level. It can be seen through the centralistic tendency in policy making. In grass root level, the party will be limited to a minimum so as not to hinder the programs that become the objectives of political party leaders. Parindo party has complete organization from DPP to DPC with the number of stewardship reaches at $100 \%$. This exceeds the amount required by rule about the formation of political parties. However, in the field, Perindo offices in each region are only as a complement to the party and as a party machine in getting the masses. In the party's true decision-making, all decisions of the Perindo party are and must go through the decision of Harry Tanoesoedibjo as chairman.

2. Organizational Structure of Intensive Capital and Professional

Characteristics of the party model of business firms can be seen in terms of internal management that are more intensive capital and professional. In Perindo party, basically it is not separated from HT's role as the main director of MNC Group. In an interview with Hendrik $\mathrm{K}$ Luntungan, he stated that Harry Tanoesodibjo builds party relationships together with entrepreneur friends who have a same vision and commitment with HT to build Perindo. Most of DPP's member structures are the people who work inside HT's MNC Company. In the Hatta Abdi Muhammd (2017), stated that in building the party structure of Perindo in the region, HT uses emotional closeness with the same background of ethnic or religious background which is then supported by the same profession of businessman in MNC Group [12].

\section{CONCLUSION}

The emergence of a business party model in Indonesia signifies a change in the development of democratization in Indonesia. Although, Perindo as a new political party remains untested in the election, at least it provides a new political model not only dominated by the old elite groups of the New Order that are re-emerging after reformation, but also by new elite groups. In addition, the emergence of Perindo also indicates a change in the pattern of large corporate political movements that is initially only as a hunter rent, then transformed into a political party used as an instrument in obtaining power within the country. Finally, if Perindo succeeds in the 2019 election, it will have a major impact on the pattern of organizing political parties that no longer rely on social basis and ideology, but rather emphasize the pragmatic rational aspect.

\section{ACKNOWLEDGMENT}

This paper would not have been possible without discussion of some friends. We are especially indebted to some informants who have given much data about this topic.

\section{REFERENCES}

[1] L. Castle, and H. Feith, Pemikiran politik Indonesia 1945-1965, Jakarta: LP3ES, 1988. 
[2] D. Dhakidae, Partai-partai politik Indonesia, Jakarta: Kompas, 1999.

[3] K. Ambardi, Mengungkap Politik Kartel: studi tentang sistem kepartaian di Indonesia era reformasi. Kepustakaan Populer Gramedia bekerjasama dengan Lembaga Survei Indonesia, 2009.

[4] M.F. Aminuddin, and M.F.S. Ramadlan, Match-All party: pragmatisme politik dan munculnya spesies baru partai politik di Indonesia pasca Pemilu 2009. Jurnal Politik, 1 (1), 2015, pp. 39-74.

[5] A. Krouwel, Party models, in Handbook of Party Politics, London: Sage Publications, 2015.

[6] R.K. Yin, Case study research: design and method (3rd ed), CA: Sage, 2003.
[7] Interview with Sahrianta, Jakarta, July 17, 2017.

[8] Interview with Rahmat, Jakarta, July 10, 2017.

[9] Interview with Sahrianta.

[10] Interview with Rimhot Turnip, Jakarta, July 10, 2017.

[11] Interview with Armyn Gultom, Jakarta, July 5, 2017.

[12] H.A. Muhammad, Pembangunan Pelembagaan Partai Persatuan Indonesia Sebagai Partai Politik Baru di Indonesia, Surabaya: Universitas Airlangga, 2017. 